\title{
PENGARUH PENDIDIKAN \\ TERHADAP ESENSI PEMBANGUNAN EKONOMI \\ (Survei pada Sekolah Menengah Pertama Negeri di Kota Depok)
}

\author{
ALIE SADIKIN ${ }^{1}$, RINOVIAN RAIS ${ }^{2}$ \\ aliesadikin@ibm.ac.id ${ }^{1}, \underline{\text { rinovianrais@ibm.ac.id }}{ }^{2}$

\section{Program Studi Ekonomi Pembangunan', Program Studi Manajemen ${ }^{2}$ Institut Bisnis Muhammadiyah Bekasi}

\begin{abstract}
ABSTRAK
Terwujudnya kemampuan dalam kualitas pendidikan dapat terjadi dengan adanya bakat, watak, kemampuan serta hati nurani sebagai suatu terobosan dalam esensi pembangunan ekonomi sehingga menciptakan hasil produk kreatif serta inovatif dalam pendidikan ini sesuai dengan kurikulum 2013 sehingga peserta didik ditujukan dalam inovasi keilmuan yang relevan untuk dilakukan secara baik. Sehingga hasilnya akan menjadi terapan sehingga kebijakan yang diambil hasilnya terbaik bagi masyarakat.
\end{abstract}

Kata kunci: pendidikan, kesehatan, esensi pembangunan ekonomi

\section{ABSTRACT}

The quality of education can be realized if the combination of talent, character, ability and conscience as a whole is part of a breakthrough, the results of education will create creative and innovative products. In line with the socialization of the 2013 curriculum, students are directed to create a science and become relevant to be implemented in the real world. The results that become applied can be used as the best policy for the community.

Key words: education, health, the essence of economic development

\section{PENDAHULUAN}

\section{Latar Belakang}

Kesuksesan masing-masing kota dan kabupaten yang ada di dalam sebuah provinsi dalam melaksanakan kebijakan ekonomi, merupakan keberhasilan dari provinsi disebut juga. Begitupun dengan yang terjadi di Jawa Barat. Apabila masing-masing kota dan kabupaten yang dibawahinya sukses melaksanakan kebijakan ekonomi, itu berarti adalah keberhasilan Jawa Barat secara menyeluruh. 
Kualitas atau mutu dari sebuah pembangunan bisa dilihat dari tingginya produktivitas pembangunan karena keberhasilan pengelolaan sumber daya yang ada oleh SDM yang andal. Sedangkan untuk membentuk SDM yang andal sangat dibutuhkan pendidikan yang memadai. Kebutuhan akan SDM yang andal sangatlah krusial, sebab SDM merupakan salah satu modal dasar dari pembangunan.

Sejak dahulu, pendidikan telah dijadikan sebagai salah satu determinan penting bagi sukses tidaknya seorang individu. Orang-orang dengan pendidikan tinggi, mulai dari sarjana strata satu hingga professor menempati peringkat prestise tertinggi dalam kehidupan baik kacamata sosial maupun ekonomi. Perihal pendidikan, bisa dipandang dari berbagai pendekatan atau sudut pandang. Di antaranya dari pendekatan pendidikan sebagai modal manusia dan pendidikan dari sisi faedah atau manfaat.

\section{Sejarah Kota Depok}

Pada abad ke-17, Cornelis Chastelein, seorang saudagar dari Belanda berhasil melakukan pembelian tanah di kota Depok seluas 12,44 $\mathrm{km}^{2}$ dengan harga 2,4 juta, serta status tanahnya bersifat partikelir atau biasa yang disebut dengan terlepas dari kekuasan pemerintah Hindia Belanda.

Berdasarkan PP nomor 43 tahun 1981, Kota Depok melakukan pemekaran kecamatan Depok dengan tujuan untuk menaikkan status, dari kecamatan menjadi kota administratif. Hasil dari pemekaran tersebut yaitu: Kota Depok terdiri atas beberapa kelurahan atau desa, yakni: Desa kemiri muka, Beji, Pondok Cina, Tanah Baru, dan Kukusan. Sedangkan untuk Kecamatan Pancoran Mas meliputi: Desa Depok, Depok Jaya, Mampang, Rangkapan Jaya, Pancoran Mas, dan Rangkapan Jaya Baru.

\section{Depok sebagai kota administratif}

Pada tahun 1982, Menteri Dalam Negeri, Amir Machmud meresmikan perubahan Kecamatan Depok menjadi kota administratif dengan menambah kecamatan sukmajaya yang tadinya masuk Kabupaten Bogor. Dengan demikian, Kota Depok merupakan kota administratif keempat di Jawa Barat setelah sebelumnya hanya ada Tasikmalaya, Cimahi, dan Tangerang. Mochammad Rukasah Suradimadja diangkat sebagai wali kota administratif pertama Kota Depok oleh Gubernur Jawa Barat Aang Kunaefi. Pada tahun 1999 awal, Kota Administratif Depok mengalami pemekaran dan semua desa berubah menjadi kelurahan, sebagai berikut: 
1. Kecamatan Beji terdiri dari: Kelurahan Tanah Baru, Pondok Cina, Kukusan, Beji, Beji Timur, dan Kemiri Muka.

2. Kecamatan Pancoran Mas terdiri dari: Kelurahan Rangkapan Jaya, Depok, Depok Jaya, Pancoran Mas, Mampang, serta Rangkapan Jaya Baru.

3. Kecamatan Sukmajaya, terdiri dari: Kelurahan Jatimulya, Cisalak, Kalibaru, Tirta jaya, Abadi Jaya, Bakti Jaya, Kalimulya, Sukmajaya, Cilodong, Mekar Jaya, dan Sukamaju.

4. Berdasarkan aspirasi masyarakat, terbentuklah Kota Depok pada 27 April 1999. Di dalamnya membawahi tiga kecamatan dan kemudian ditambah satu lagi yang sebelumnya merupakan bagian dari wilayah Kabupaten Bogor. Sehingga kemudian Kota Depok terdiri dari: Kecamatan Sawangan, Cimanggis, Limo, serta ditambah 5 desa lagi dari Kecamatan Bojong Gede.

Dengan demikian, pada akhirnya, wilayah Kabupaten Bogor terdiri atas enam kecamatan, yakni:

1. Kecamatan Sawangan, meliputi: Kelurahan Duren Mekar, Kelurahan Duren Seribu, Kelurahan Curug, Kelurahan Pondok Petir, Kelurahan Serua, Kelurahan Bojongsari Baru, Kelurahan Bojongsari Lama, Kelurahan Sawangan Lama, Kelurahan Sawangan Baru, Kelurahan Pasir Putih, Kelurahan Bedahan, Kelurahan Pengasinan, Kelurahan Kedaung, dan Kelurahan Cinangka.

2. Kecamatan Sukmajaya, meliputi: Kelurahan Cilodong, Kelurahan Sukamaju, Kelurahan Jati Mulya, Kelurahan Kalimulya, Kelurahan Kali Baru, Kelurahan Cisalak, Kelurahan Sukmajaya, Kelurahan Bakti Jaya, Kelurahan Tirta Jaya, Kelurahan Abadi Jaya, serta Kelurahan Mekar Jaya.

3. Kecamatan Pancoran Mas, meliputi: Kelurahan Pondok Jaya, Kelurahan Bojong Pondok Terong, Kelurahan Ratu Jaya, Kelurahan Depok, Kelurahan Pancoran Mas, Kelurahan Depok Jaya, Kelurahan Cipayung Jaya, Kelurahan Cipayung, Kelurahan Rangkapan Jaya Baru, Kelurahan Rangkapan Jaya, serta Kelurahan Mampang.

4. Kecamatan Limo, meliputi: Kelurahan Pangkalan Jati Baru, Kelurahan Grogol, Kelurahan Gandul, Kelurahan Pangkalan Jati, Kelurahan Cinere, Kelurahan Krukut, Kelurahan Limo, serta Kelurahan Meruyung. 
5. Kecamatan Cimanggis, meliputi: Kelurahan Cilangkap, Kelurahan Sukatani, Kelurahan Sukamaju Baru, Kelurahan Jatijajar, Kelurahan Cimpaeun, Kelurahan Leuwinanggung, Kelurahan Mekarsari, Kelurahan Curug, Kelurahan Harjamukti, Kelurahan Tapos, Kelurahan Pasir Gunung Selatan, Kelurahan Tugu, serta Kelurahan Cisalak Pasar.

6. Kecamatan Beji, meliputi: Kelurahan Tanah Baru, Kukusan, Beji, Kemiri Muka, Beji Timur, serta Kelurahan Pondok Cina.

\section{Kecamatan dimekarkan lagi}

Pada 2007, Kota Depok kembali melakukan pemekaran dan disahkan oleh DPRD Kota Depok, sebagai berikut:

1. Kecamatan Sukmajaya, terdiri dari: Kelurahan Cisalak, Kelurahan Tirta Jaya, Kelurahan Abadi Jaya, Kelurahan Bakti Jaya, Kelurahan Mekar Jaya serta Kelurahan Sukmajaya.

2. Kecamatan Cilodong, terdiri dari: Kelurahan Kalibaru, Cilodong, Sukamaju, Kalimulya, dan Jatimulya

3. Kecamatan Pancoran Mas terdiri dari: Kelurahan Depok, Depok Jaya, Pancoran Mas, Mampang, Rangkapan Jaya, serta Rangkapan jaya baru.

4. Kecamatan Cimanggis, terdiri dari: Kelurahan Curug, Harjamukti, Pasir Gunung Selatan, Cisalak Pasar, Tugu, serta Mekarsari.

5. Kecamatan Tapos, terdiri dari: Kelurahan Cimpaeun, Cilangkap, Jatijajar, Leuwinanggung, Sukamaju Baru, Tapos, serta Sukatani.

6. Kecamatan Cipayung, terdiri dari: Kelurahan Pondok Jaya, Kelurahan Bojong Pondok Terong, Kelurahan Cipayung, Kelurahan Ratu Jaya serta Kelurahan Cipayung Jaya.

7. Kecamatan Sawangan, terdiri dari: Kelurahan Pasir Puth, Sawangan Lama, Sawangan Baru, Bedahan, Pengasinan, Kedaung, serua Cinangka.

8. Kecamatan Limo, terdiri dari: Kelurahan grogol, Limo, Krukut, serta Meruyung.

9. Kecamatan Bojongsari, meliputi: Kelurahan Bojongsari Lama, Bojongsari Baru, Duren Seribu, Pondok Petir, serua, Duren Mekar, dan Curug.

10. Kecamatan Beji, terdiri dari: Kelurahan Pondok Cina, Tanah baru, Kukusan, Beji, Kemiri Muka, dan Beji Timur,

11. Kecamatan Cinere, terdiri dari: Kelurahan Pangkalan Jati Baru, Gandul, Cinere, serta Pangkalan jati.

\section{Kota Depok mempunyai perkampungan}

Jumlah total perkampungan atau kelurahan di Kota Depok pada saat ini ada 63 kelurahan dan 11 kecamatan. Sebelumnya masih berstatus desa bukan kelurahan dimana ini merupakan suatu ciri kelurahan bersifat urban (perkotaan) sedangkan desa bercirikan rural (pedesaan). 
Lambat laun mulai berkurang dipopulerkan serta menghilang seperti kampung bedahan, kampung perigi yang ada di kecamatan sawangan, dimana desa-desa tersebut telah menjadi kelurahan dimana sebelumnya menjadi desa.

\section{Luas Kota Depok}

Jumlah Penduduk Kota Depok saat ini 2.484.000 Jiwa, luas daerah 200,29 km, dengan 11 kecamatan dan 63 kelurahan.

\section{TINJAUAN PUSTAKA}

\section{Konteks produktivitas pada pendidikan serta kesehatan}

Meningkatnya pengembalian investasi pada pendidikan serta kesehatan menjadikan Kota Depok mempunyai modal bagi masyarakatnya, sehingga akan tercapai indek pembangunan manusia di kota depok yang berkaitan dengan pendidikan serta kesehatan sebagai esensi pembangunan ekonomi Kota Depok.Modal kesehatan merupakan faktor penting bagi kehadiran anak didik di sekolah formal.

Pendidikan sangat diperlukan untuk pembentukan karakter serta pelatihan petugas baik pendidikan maupun untuk kesehatan. Peningkatan efisiensi produktivitas investasi kesehatan serta pendidikan akan membuat pengembalian atas investasi pendidikan serta kesehatan menjadi tinggi pula, dimana kedua investasi tersebut akan bisa meningkatkan harapan hidup manusia Kota Depok. Semakin besar modal kesehatan dan pendidikan, bisa membuat pengembalian atas investasi di bidang kesehatan dan pendidikan semakin meningkat. Sebab, banyak dari program kesehatan serta pendidikan yang bergantung pada keterampilan dasar. Sedangkan keterampilan dasar tersebut didapatkan dari belajar di sekolah.

Untuk profil kesehatan di Provinsi Jawa Barat, penderita penyakit paru-paru hanya tinggal $3,42 \%$ saja dari total jumlah penduduk. Dari seluruh penderita penyakit tersebut, peluang kesembuhannya mencapai $84,6 \%$. Itu artinya, ada banyak jumlahnya pasien yang tertolong oleh tenaga kesehatan di Jawa Barat. Sebuah pencapaian yang sangat memuaskan.

Pada penderita Pneumonia anak balita berkisar 36,250\%. Sementara demam berdarah berkisar 43,55\% kejadian, sehingga kejadian tersebut dapat diminimalisir karena adanya yang terawat serta pada kondisi yang sangat serius berkisar 6,789\%. Sementara penderita malaria, belum tidak kasus penderitanya begitu juga dengan insidennya beberapa penyakit yang ada di provinsi Jawa Barat secara umum.

Sedangkan penderita kusta di Jawa Barat, untuk jenis kusta PB mencapai 42 orang, sedangkan kusta MB sebanyak 201 orang. Untuk penderita filaris ada sebanyak 214 pasien. Sementara itu, untuk difteri tidak terdapat satu orang pun. 
Tabel 1. Database Kesehatan Jawa Barat

\begin{tabular}{|l|l|l|l|l|l|l|l|l|l|l|l|l|}
\hline No. & Provinsi & \multicolumn{2}{|l|}{ Jenis Penyakit dan Kesembuhan } \\
\cline { 3 - 10 } & & $\begin{array}{l}\text { AFP Rate } \\
\text { <15 Thn } \\
\text { (per } \\
1000)\end{array}$ & $\begin{array}{l}\text { Paru TB } \\
\text { Sembuh }\end{array}$ & $\begin{array}{l}\text { Jumlah } \\
\text { Penderita } \\
\text { Pocumonea } \\
\text { balita }\end{array}$ & $\begin{array}{l}\text { Insiden } \\
\text { DBD } \\
\text { (per } \\
1000)\end{array}$ & $\begin{array}{l}\text { Jumlah } \\
\text { penderi } \\
\text { ta } \\
\text { DBD }\end{array}$ & $\begin{array}{l}\text { Jumlah } \\
\text { Penderi } \\
\text { ta } \\
\text { Malari } \\
\text { a }\end{array}$ & $\begin{array}{l}\text { Insiden } \\
\text { Malari } \\
\text { a per } \\
1000)\end{array}$ & $\begin{array}{l}\text { Jumlah } \\
\text { penderi } \\
\text { ta } \\
\text { kusta } \\
\text { PB }\end{array}$ & $\begin{array}{l}\text { Jumlah } \\
\text { penderi } \\
\text { ta kusta } \\
\text { MB }\end{array}$ & $\begin{array}{l}\text { Juml } \\
\text { ah } \\
\text { pend } \\
\text { erita } \\
\text { filari } \\
\text { asis }\end{array}$ & $\begin{array}{l}\text { Juml } \\
\text { ah } \\
\text { pend } \\
\text { erita } \\
\text { difter } \\
\text { i }\end{array}$ \\
\hline 1. & $\begin{array}{l}\text { Jawa } \\
\text { Barat }\end{array}$ & 3,42 & 84,63 & 36,250 & 41,55 & 4,697 & 0 & 0 & 37 & 163 & 141 & 0 \\
\hline
\end{tabular}

Data bersumber: http://www.bankserta data.depkes.go.id

Pada tabel diatas dimana untuk pendidikan juga terdapat 6 daftar tabel tingkat pendidikan diantaranya 1). Berupa angka harapan hidup, 2). Berupa angka yang melek terhadap huruf, 3). Dimana setiap anak didik yang mempunyai lama sekolah, 4). Dimana angka perkapita yang sudah disesuaikan, 5). Pada angka indek pembangunan manusia kota depok.

Adapun peranan pendidikan dalam pembangunan adalah, pendidikan akan berpengaruh terhadap pola pikir masyarakat. Seiring berjalannya waktu, terjadi pembaharuan atau inovasi dalam sistem pendidikan yang ada. Hal itu terkait dengan penggunaan teknologi dalam proses belajar. Sehingga, kemudian menghasilkan tenaga kerja yang andal dan mandiri.

Tabel 2. Variabel Pendidikan Jawa Barat

\begin{tabular}{|l|c|c|c|c|c|}
\hline Variabel & \multicolumn{5}{|c|}{ Jawa Barat } \\
\cline { 2 - 6 } & 2016 & 2017 & 2018 & 2019 & 2020 \\
\hline $\begin{array}{l}\text { Berupa angka } \\
\text { harapan hidup }\end{array}$ & 87.35 & 88.65 & 80.79 & 88.74 & 86.78 \\
\hline $\begin{array}{l}\text { Berupa angka } \\
\text { yang melek } \\
\text { terhadap huruf }\end{array}$ & 99.88 & 99.95 & 99.46 & 99.53 & 99.52 \\
\hline $\begin{array}{l}\text { Dimana setiap } \\
\text { anak didik yang } \\
\text { mempunyai } \\
\text { lama sekolah }\end{array}$ & 9.95 & 9.98 & 9.97 & 9.99 & 9.97 \\
\hline $\begin{array}{l}\text { Dimana angka } \\
\text { perkapita yang } \\
\text { sudah } \\
\text { disesuaikan }\end{array}$ & 748.79 & 725.65 & 764.44 & 754.55 & 765.56 \\
\hline $\begin{array}{l}\text { Pada angka } \\
\text { indek } \\
\text { pembangunan } \\
\text { manusia kota } \\
\text { depok. }\end{array}$ & 85.84 & 85.9 & 85.79 & 85.74 & 86.71 \\
\hline
\end{tabular}

Data bersumber: biro pusat statistik provinsi jawa barat. 
Pada tabel di atas, berisi angka harapan hidup, yang merupakan alat monitoring dan evaluasi kinerja pemerintah dalam upaya peningkatan kesejahteraan penduduk Kota Depok. Menurut angka-angka pada tabel tersebut menunjukkan, bahwa angka harapan hidup pada Provinsi Jawa Barat yang didapat dari Biro Pusat Statistik tahun 2016 s/d 2020, adalah 87,35. Itu berarti, bayi-bayi yang lahir tahun 2016 bisa hidup hingga 87 tahun. Pada Tahun 2019, tingkat harapan hidup bayi yang terlahir di Provinsi Jawa Barat mengalami penurunan, yakni menjadi 86 tahun. Tahun 2020 angka harapan hidup bayi yang dilahirkan menjadi 86 s.d 87 tahun.

\section{Konteks produktivitas pada pendidikan dan kesehatan}

Direktur jenderal pendidikan Syawal Gultom dalam seminar pendidikan nasional di universitas medan pada tahun 2013 memberlakukan kurikulum 2013 pada tahun 2013 dan 2014 dengan alasan sebagai berikut:

1. Adanya pembelajaran sebagai proses perubahan apakah itu dari siswa untuk mencari tahu ilmu pengetahuan serta proses nilai berbasis hasil yang menjadi proses serta hasil juga memerlukan penambahan jam pembelajaran siswa.

2. Banyak negara juga menambah jam pelajaran sebagai inovasi dalam pembelajaran.

3. Negara-negara lain juga menunjukan jam pembelajaran termasuk di indonesia yang materi pembelajarannya juga relatif sedikit atau singkat.

Adapun pembahasan kurikulum beberapa tahap yakni:

1. Kurikulum di lingkungan internal Kementerian pendidikan dan kebudayaan yang melibatkan para ahli dari bermacam-macam disiplin ilmu, serta praktisi pendidikan dalam pembahasan kurikulum 2013,

2. Desain pemaparan kurikulum 2013 juga dibahas di depan wakil presiden yang selaku komite pendidikan serta di depan komisi X DPR RI semua dibahas secara bersama-sama.

3. Disini pelaksanaan kurikulum 2013 diuji coba guna menanggapi tanggapan dari kepala sekolah atau guru-guru serta masyarakat juga ikut.

4. Penyempurnaan kurikulum 2013 disempurnakan dan sekaligus ditetapkan dalam pelaksanaannya yang telah dijadikan suatu pengembnagan kurikulum untuk dapat dikembangkan dalam masyarakat.

Pelaksanaan kurikulum 2013 dalam perkembangannya juga telah diuji coba dalam masyarakat sehingga tidak akan terjadi miskomunikasi antar stakeholder pendidikan. Dalam perkembangannya, kurikulum 2013 telah sesuai dengan esensi pembangunan ekonomi dalam bidang pendidikan. Dalam hal ini pendekatan kerakyatan lebih dikedepankan. 


\section{Pembangunan sebagai dasar pengerahan pendidikan}

Umumnya biaya pendidikan masih masuk dalam kategori tinggi, sehingga banyak masyarakat tak mampu menjangkaunya. Pendidikan yang ditanggung sendiri (biaya pribadi/private cost) lebih meningkat lamban atau bahkan juga menurun. Masalah juga bermanfaat biaya sosial terhadap intervensi kebijakan publik serta swasta dengan adanya bantuan dana dan beasiswa yang ada untuk melebihi dari nilai sosialnya jangan sampai siswa atau peserta didik terlantar atau siswa jadi tidak sekolah.

Masalah pengangguran menjadi persoalan yang dilematis dan mesti dipikirkan dan diperhatikan dengan lebih lagi. Sebab hal tersebut tidak terlepas dari masalah pelaksanaan dari program pendidikan yang dicanangkan. Satu lagi masalah yang sangat krusial adalah peningkatan kualitas pendidikan. Sebab dengan pendidikan yang berkualitas akan melahirkan SDM-SDM andal.

\section{METODOLOGI PENELITIAN}

\section{Teknik Pengumpulan Data}

Pengaruh pendidikan terhadap esensi pembangunan ekonomi di kota depok (survei pada SMP Negeri Di Kota Depok) yang digunakan pada data primer dan sekunder dimana data dikumpulkan dan dijadikan sampel untuk mengukur efektifitas pengaruh kesehatan serta pendidikan terhadap esensi pembangunan ekonomi di kota depok.

Sumber yang tidak langsung juga memberikan data kepada peneliti baik oleh guru, kepala sekolah atau siswa dan lain-lain dan data dari pemerintah seperti biro pusat statistik pusat atau daerah sehingga data yang dimiliki mempunyai struktur dan hasil yang efektif dalam suatu pengambilan keputusan bagi peneliti.

\section{Data Analisis}

Data analisis dengan menggunakan sampel serta dari statistik deskriptif sehingga Hasil yang didapat valid dan reliabel yang menggambarkan terkumpul sebagaimana membuat pembahasan serta membuat kesimpulan yang sudah berlaku umum serta kesemuanya yang diambil dari populasi yang ada pada SMP Negeri di Kota Depok yang jelas akan mengambil statistik deskriptif yang berlaku.

\section{Lokasi pelaksanaan}

Lokasi dari penelitian ini yaitu beberapa sekolah di Kecamatan Sawangan: (SMP Negeri 10), (SMP Negeri 25), 
Kecamatan Pancoran Mas: (SMP Negeri 20), Kecamatan Sukmajaya: (SMP Negeri 22), Kecamatan Cimanggis: (SMP Negeri 7), (SMP Negeri 8), (SMP Negeri 15), Kecamatan Beji: (SMP Negeri 26), Kecamatan Limo: (SMP Negeri 13), Kecamatan Cipayung: (SMP Negeri 9), Kecamatan Cilodong: (SMP Negeri 6), Kecamatan Cinere: (SMP Negeri 17), (SMP Negeri 21), Kecamatan Tapos: (SMP Negeri 11), (SMP Negeri 12), (SMP Negeri 16), (SMP Negeri 24), Kecamatan Bojongsari: (SMP Negeri 14), (SMP Negeri 18). SMP Swasta Mardi Yuana Kota Depok, SMP Permata Kota Depok, SMP Swasta PSKD 6 Kota Depok, SMP Swasta Al Farabi. SMP Swasta Bintara Sawangan Kota Depok.

\section{PEMBAHASAN}

Di Kota Depok perguruan tinggi negeri dan perguruan tinggi swasta yaitu:

1. Universitas Indonesia (UI), Universitas Indonesia merupakan salah satu perguruan tinggi favorit di Indonesia yang beralamat di Jalan Margonda Raya, Beji, Depok.

2. Universitas Gunadarma (Gundar), Universitas Gunadarma beralamat di Jalan Margonda Raya, Beji, Depok. Kemudian kampus kedua didirikan di Jalan Komjen Pol M. Jasin, Depok. Kampus Universitas Gunadarma juga ada yang berlokasi di Tangerang, Bekasi, dan Jakarta.

3. Politeknik Negeri Jakarta (PNJ), Politeknik Negeri Jakarta sebelumnya merupakan bagian dari Universitas Indonesia, pada fakultas non-gelar teknologi. Kemudian, PNJ berdiri sendiri meskipun lokasinya berada di dalam kompleks UI. Nama PNJ digunakan mulai 25 Agustus 1998 yang sebelumnya bernama Politeknik Universitas Indonesia sejak tahun 1982.

4. STEI SEBI, STEI (Sekolah Tinggi Ekonomi Islam) SEBI berada di Jalan Raya Bojongsari, Sawangan, Depok. Program studi yang ditawarkan oleh kampus ini hanya dua yaitu Perbankan Syariah dan Akuntansi Syariah.

5. STIE Manajemen Bisnis Indonesia, Lokasi kampus ini tak jauh dari Universitas Indonesia (UI), yaitu tepatnya di Jalan Komjen Pol M Jasin, Tugu, Cimanggis.

6. STT Terpadu Nurul Fikri (STT NF), Sekolah Tinggi Teknologi Terpadu Nurul Fikri didirikan pada tahun 2012. Sekolah tinggi ini berawal dari sebuah pelatihan komputer yang kemudian berkembang menjadi program D1 dan D2. Jurusan yang ditawarkan di STT yang berada di Jalan Situ Indah, Tugu, Cimanggis, Depok ini yaitu Teknik Informatika dan Sistem Informasi. 
7. STIE Fajar, STIE Fajar beralamat di Jalan Raya Sawangan, Pancoran Mas, Depok. Jurusan yang ada di sini ialah S1 Manajemen dan Akuntansi D3 dan S1.

8. STAI Al Hamidiyah, Sekolah Tinggi Agama Islam Al Hamidiyah berada di Jalan Raya Sawangan, Pancoran Mas, Depok. Sekolah tinggi ini berada di dalam kompleks Pondok Pesantren Al Hamidiyah.

9. STIKES Raflesia, STIKES Raflesia beralamat di Komplek Pondok Duta, Jl. Mahkota Raya No.32B, Cimanggis, Depok. Program studi yang ditawarkan di kampus ini adalah D3 Keperawatan dan S1 Kesehatan. Di gedung kampus yang berdiri sejak tahun 1992 ini, STIKES Raflesia mempunyai fasilitas laboratorium, perpustakaan, klinik, asrama, masjid, dan kantin serta tempat parkir yang cukup luas.

Tabel 3. Variabel Pendidikan Kota Depok

\begin{tabular}{|l|c|c|c|c|c|}
\hline Variabel Kota Depok & \multicolumn{3}{|c|}{} \\
\cline { 2 - 6 } & 2016 & 2017 & 2018 & 2019 & 79.53 \\
\hline $\begin{array}{l}\text { Berupa angka } \\
\text { harapan hidup }\end{array}$ & 78.32 & 79.45 & 79.52 & 99.66 & 99.57 \\
\hline $\begin{array}{l}\text { Berupa angka } \\
\text { yang melek } \\
\text { terhadap huruf }\end{array}$ & 99.68 & 99.75 & 99.82 & & \\
\hline $\begin{array}{l}\text { Dimana setiap } \\
\text { anak didik yang } \\
\text { mempunyai } \\
\text { lama sekolah }\end{array}$ & 9.70 & 9.83 & 9.88 & 9.89 & \\
\hline $\begin{array}{l}\text { Dimana angka } \\
\text { perkapita yang } \\
\text { sudah } \\
\text { disesuaikan }\end{array}$ & 737.83 & 735.81 & 736.82 & 740.33 & 753.53 \\
\hline $\begin{array}{l}\text { Pada angka } \\
\text { indek } \\
\text { pembangunan } \\
\text { manusia kota } \\
\text { depok. }\end{array}$ & 85.33 & 85.35 & 85.43 & 85.55 & \\
\hline
\end{tabular}

Sumber: Data BPS Kota Depok

Data di atas berupa angka harapan hidup di Kota Depok. Data didapatkan dari dari BPS dari tahun 2016 hingga 2020. Dari sana bisa dilihat, pada tahun 2016 angka harapan hidupnya mencapai 78,32 tahun. Itu berarti, bayi yang dilahirkan tahun 2016 akan bisa hidup hingga 78 tahun dan tidak jauh berbeda tahun 2017. Tahun 2018, tingkat harapan hidup penduduk Kota Depok mencapai 78 tahun. 
Tahun 2018 juga mencapai 87 tahun. Tingkat harapan hidup bayi yang lahir di Kota Depok meningkat menjadi 78 tahun dan Tahun 2019 angka harapan hidup bayi yang dilahirkan menjadi 78. Apabila dilakukan perbandingan dengan Jawa Barat, angka harapan hidup Kota Depok tetap di angka yang sama. Dengan demikian, Kota Depok bisa dikategorikan ke dalam daerah yang mempunyai angka harapan hidup relatif baik.

Tingkat kesehatan juga memiliki pengaruh terhadap tingkat pembangunan ekonomi di Kota Depok. Apabila dilihat dari profil kesehatannya, jumlah penderita penyakit paruparu mencapai $0 \%$. Sebab banyak pasien yang ditolong oleh tenaga kesehatan Kota Depok. Sedangkan penderita yang bisa diselamatkan mencapai 34,32\%. Hal itu merupakan pencapaian yang sangat memuaskan. Banyaknya pasien Pneumonia balita $0 \%$, demam berdarah $85 \%$ kasus. Akan tetapi, dapat terminimalisir, sebab yang mengalami kondisi serius cuma 15,98\% Malaria 0, 18\%. Tidak ada pasien kusta. Filaris mencapai 18 orang penderita, serta tak ada penderita difteri. Oleh karena itu Kota Depok masuk dalam kategori efektif untuk hal kesehatannya.

Selain itu, Pendidikan di Kota Depok terbilang baik. Dari hasil penelitian sebelumnya yang dilakukan di beberapa SMP Negeri dan swasta, menghasilkan:

1. Pendidikan meliputi produktivitas guru dalam kesejahteraannya guru, siswa ikut sekolah dalam pendidikan yang mempunyai peran yang sangat penting bagi pembangunan ekonomi kota depok.

2. Proses penyelenggaraan pendidikan juga merupakan bagian terpenting dalam peningkatan kualitas pendidikan itu sendiri. Ada perbedaan dalam kurikulum 2013 versus KTSP. Hal itu dikarenakan adanya perbedaan dalam sosialisasi dan tempat sosialisasi kurikulum 2013 itu sendiri beserta esensinya yang diharapkan menjadi faktor peningkat kualitas siswa.

3. Pendidikan yang dikerahkan sebagai modal pembangunan kota depok yang juga banyak disarankan oleh stakeholder pendidikan dalam meningkatkan taraf hidup dan memberantas buta huruf di kota depok.

\section{Produktivitas Pendidikan Kota Depok (Survei pada SMP Negeri di Kota Depok)}

Proses perubahan siswa yang menuju pendewasaan ini sudah sesuai dengan sistem yang ada seperti dalam kurikulum 2013 ini dengan pencerdasan serta pematangan diri siswa yang diperlukan adanya perkembangan badan serta kecerdasan siswa

Serta perkembangan jiwa siswa yang juga dalam perilaku dalam kegiatan pendidikan keatas seperti SMA, dimana kerangka budaya belajar seperti merdeka belajar dalam kehidupan manusia. 


\section{Pendidikan sebagai aspek perkembangan siswa}

Pendidikan dilihat dalam perkembangan pendidikan yang telah dicapai keefektifan pencapaian masyarakat dimana peranan guru, kepala sekolah dan stakeholder yang memberikan pengajaran untuk dimengerti mengenai perkembangan pendidikan terutama pada siswa SMP Negeri di kota depok yang dapat meningkat secara signifikan kualitas pendidikannya.

Yang memberikan jawaban terhadap aspek perkembangan sis pertanyaan siswa oleh guru sebanyak 75 guru di kota depok yang menjawab sebanyak 65 orang guru dan 10 belum menjawab.

\section{Kesejahteraan Guru}

Kesejahteraan guru juga menjadi bagian penting dalam dunia pendidikan. Sebab, guru merupakan subjek sekaligus stakeholder dunia pendidikan. Kesejahteraan guru akan sangat mempengaruhi kualitas out pendidikan. Tingkat kesejahteraan guru yang tinggi akan turut andil dalam menghasilkan guru-guru yang andal.

Survei dilakukan terhadap 75 orang guru untuk diajukan pertanyaan perihal kesejahteraannya. Dari 75 orang tersebut, 65 orang menjawab lumayan baik perihal kesejahteraannya, sedangkan 10 orang menyatakan kurang bagus perihal kesejahteraannya. Rata-rata, guru yang menjawab telah mencapai kesejahteraan yang lumayan bagus itu adalah guru-guru dari sekolah negeri. Sedangkan yang kurang baik kesejahteraannya adalah guru-guru sekolah swasta yang ada di wilayah Kota Depok. Dengan demikian, bisa dikatakan kesejahteraan guru di Kota Depok masuk kategori memadai atau bagus.

\section{Pendidikan dalam partisipasi siswa}

Hal utama dalam pendidikan adalah menanamkan nilai-nilai baik untuk kehidupan. Partisipasi siswa dalam proses penanaman tersebut sangatlah penting, sebab menentukan berhasil atau tidaknya, serta efektif atau tidaknya proses penanaman dan pembelajaran tersebut.

Berdasarkan dari jawaban pertanyaan yang diberikan kepada para guru sehubungan dengan partisipasi siswa, 45 orang menjawab kurang puas. Sedangkan 30 orang guru menjawab cukup baik. Dengan demikian mengindikasikan kondisi yang hampir berimbang.

\section{Peningkatan pendidikan sebagai peran dari otoritas pendidikan}

Peningkatan pendidikan merupakan domain dari otoritas utama pendidikan untuk menuju ke arah pendidikan yang lebih baik lagi. 
Jumlah guru 75 orang yang dijadikan penelitian mengenai otoritas utama pendidikan dengan opsi jawaban yang diberikan baik oleh guru, pemerintah kota depok, kepala sekolah serta kombinasi ketiganya guru yang menjawab sebanyak 65 guru yang menjawabnya serta 10 orang guru lainnya yang menjawab tanggung jawab ada di pemerintah kota depok.

\section{Proses penyelenggaraan Pendidikan (Survei Pada SMP Negeri di Kota Depok) Pendidikan yang mempunyai kualitas meningkat}

Proses penyelenggaraan pendidikan sangat menentukan kualitas dari anak didik. Dari 75 orang guru yang ditanyai, 55 orang guru menjawab dibutuhkannya sarana dan prasarana pendidikan yang mendukung. 15 orang menjawab diperlukannya penyelenggaraan diklat bagi guru serta studi banding ke sekolah yang berprestasi, dan 5 orang guru menjawab butuh kerjasama antara guru, orangtua siswa, serta pemerintah Kota Depok dalam rangka meningkatkan kualitas pendidikan.

\section{Kurikulum 2013 vs KTSP dalam perbedaan}

Seperti halnya daerah lain di seluruh Indonesia, Kota Depok pun menerapkan kurikulum 2013 sebagai kurikulum sekolah. Konsep yang ada pada kurikulum ini dipandang sangat menyulitkan bagi siswa untuk bisa melakukan aktivitas lain di luar pelajaran. Belum lagi persoalan ulangan-ulangan dan buku pelajaran yang belum sampai ke sekolah padahal ulangan semester telah berlangsung. Dengan demikian pelaksanaan kurikulum ini bisa dikatakan belum berjalan dengan baik.

\section{Sosialisasi Kurtilas (kurikulum dua ribu tiga belas)}

Kurtilas atau disebut dengan kurikulum dua ribu tiga belas sangat diperlukan dalam peningkatan pengetahuan peserta didik yang merupakan jembatan dalam peningkatan kompetensi siswa. Dari 75 orang guru yang di-survei, 55 orang guru yang sudah sosialisasi perihal kurikulum 2013. Sedangkan 20 orang lainnya belum melakukan sosialisasi.

Sebenarnya, guru telah siap untuk menerapkan kurikulum 2013 kepada siswa SMP negeri di Kota Depok. Akan tetapi, pada pelaksanaannya masih terkendala oleh beberapa hal, seperti buku dan sistem pembelajaran. Apabila dilihat dari grafik, masih $80 \%$ saja guru yang sudah memperoleh sosialisasi kurikulum 2013 dan siap mengaplikasikannya. Sedangkan yang $20 \%$ lainnya masih belum. Kenyataan ini masih sangat belum memuaskan. 


\section{Esensi peningkatan kualitas siswa}

Siswa yang berkualitas merupakan modal dasar bagi pembangunan ekonomi. Di mana diharapkan, siswa mendapatkan pendidikan karakter yang baik sehingga menjadikannya sebagai tenaga yang berkualitas bagi pembangunan. Dari 75 guru, yang berpendapat soal esensi kurikulum 2013 terhadap peningkatan kualitas siswa, 20 orang guru mengatakan bahwa kurikulum 2013 belum bisa dijadikan solusi bagi pembangunan. Sedangkan 45 orang menyatakan bahwa kurikulum 2013 cukup mampu menjadi solusi, dan 10 orang guru masih dalam tahap pengerjaan. Sehingga belum bisa mengatakan pendapatnya. Dengan demikian menunjukkan bahwa kurikulum 2013, belumlah siap menjadi solusi bagi pembangunan. Masih butuh monitoring juga evaluasi secara cepat, supaya bisa menjadi solusi bagi tantangan pembangunan ekonomi Kota Depok

\section{Pengerahan Dana Pendidikan sebagai Modal untuk Pembangunan (Survei pada SMP Negeri di Kota Depok)}

Pembangunan dalam bidang pendidikan serta kesehatan diperlukan agar terjadi pergerakan manajemen sumber daya manusia secara maksimal serta mempunyai kekuatan teknologi dari berbagai sektor lainnya yang mempunyai peran dominan.

Kurikulum 2013 masih memerlukan saran untuk perbaikan dalam proses pembelajaran serta peningkatan kualitas pembangunan terdiri $45 \%$ diperlukan dalam penyediaan dalam proses pembelajaran seperti melengkapi sarana prasarana, alat peraga dalam pembelajaran, $15 \%$ menanyakan perlu perhatian dari guru dalam kesejahteraan serta $15 \%$ menyatakan perlu adanya kerjasama antara orang tua, guru, serta pemerintahan Kota Depok.

Esensi pembangunan ekonomi Kota Depok mempunyai pengaruh yang signifikan terhadap pembangunan ekonomi kota depok ada beberapa sekolah SMP Negeri di kota depok yang menjadi solusi peningkatan pembangunan yang di monitoring serta dievaluasi dalam kurikulum 2013 sehingga bila berhasil akan menjadi kebanggaan bagi Provinsi Jawa Barat. 


\section{KESIMPULAN DAN SARAN}

Berdasarkan data dari Biro Pusat statistik pada tahun 2018-2020 menunjukkan, bahwa angka harapan hidup Kota Depok sudah cukup baik. Hal itu menjadi modal yang cukup bagi pelaksanaan kurikulum pendidikan 2013. Angka melek huruf Kota Depok 2,50\% lebih besar daripada Provinsi Jawa Barat.

Dari jumlah Propinsi Jawa Barat yang ada di angka 97,51\%. Hal itu merupakan capaian yang mesti dipertahankan bahkan ditingkatkan pada tahun selanjutnya. Sebab bisa menjadi modal bagi peningkatan produktivitas pembangunan. Terdapat penurunan pengeluaran perkapita Kota Depok pada tahun 2020 sebesar Rp 19.270. Namun demikian itu tetap memperlihatkan pencapaian yang baik.

Sedangkan IPM atau Indeks Pembangunan Manusia, pada tahun 2020 menunjukkan peningkatan. Yakni mencapai umur 70 tahun. Hal itu menunjukkan bahwa di Kota Depok tingkat kesejahteraannya telah cukup baik dan menggembirakan. Dalam hal produktivitas pendidikan yang meliputi tingkat kesejahteraan guru, perkembangan pendidikan, partisipasi siswa dalam pendidikan, Otoritas utama yang berperan dalam peningkatan pendidikan telah dilakukan survei di Kota Depok dengan sampelnya guru-guru SMP Negeri di Kota Depok.

Aspek dalam perkembangan pembelajaran pendidikan sudah berada kearah yang lebih baik lagi. Dimana kesejahteran guru serta partisipasi siswa dalam pendidikan sudah menunjukkan tingkat yang lumayan bagus. Untuk mencapai kualitas pembangunan yang bagus dibutuhkan kerjasama yang baik antara pihak sekolah, masyarakat, dan pemerintah Kota Depok dalam hal pendidikan. 


\section{DAFTAR PUSTAKA}

Gultom, S., (2013). Seminar Pendidikan Nasional Unimed. Universitas Medan.

http://www.bps.go.id. (2021). BPS Jawa Barat. Retrieved Juni 15, 2021

http://www.bankdata.depkes.go.id

Sugiyono., (2019), Metode Penelitian Pendidikan (Pendekatan Kuantitatif, Kualitatif dan $R \& D)$, Bandung: Alfabeta.

Suhardan, D., Riduwan, \& Emas. (2012). Ekonomi dan Pembiayaan Pendidikan. Bandung. Penerbit: Alfabeta.

Todaro, M. P,. (2011), Pembangunan Ekonomi ,Jakarta.Penerbit: Erlangga.

Tambunan, Tulus TH (2019). Ekonomi Indonesia. Jakarta. Penerbit: Erlangga. 